\title{
HUKUM ISLAM FUNGSIONAL DI TENGAH PERUBAHAN SOSIAL
}

\author{
Oleh \\ Ahmatnijar \\ Dosen Fakultas Syariah dan Ilmu Hukum IAIN Padangsidimpuan \\ email : ahmatnijar@iain-padangsidimpuan.ac.id
}

\begin{abstract}
Abstrac
Jika perubahan sosial tiada henti dan dapat direkayasa tetapi tidak dapat melepaskan diri dari aspek hukum, maka pemikiran pengembangan hukum Islam pun harus direkayasa dan tiada boleh berhenti agar ia tetap berada dalam lingkup fungsional.
\end{abstract}

Kata Kunci; Hukum, Islam, Fungsional, Perubahan, dan Sosial

\section{A. Pendahuluan}

Manusia secara pribadi maupun kelompok, adalah makhluk berkelompok yang hidup bersama yang berinteraksi satu sama lain, baik kelompok kecil maupun kelompok besar seperti negara bangsa. Interaksi budaya di era globalisasi ini dapat mempercepat laju perubahan social, eksesnya dapat dilihat dari kesenjangan nilai lama dengan nilai baru, antara hukum yang mapan dengan realitas sosial yang terus mengalami perubahan, serta perubahan terhadap konsep pranata hukum Islam. ${ }^{1}$

Al-Qur'an maupun hadis sebagai sumber hukum Islam, merupakan korpus tertutup yang tidak bisa ditambah lagi secara kuantitas, yang secara fungsional kedua sumber ini adalah untuk mengatur berbagai aspek kehidupan manusia ditengah perubahan sosial dan permasalahan yang selalu tumbuh dan berkembang. Tentu butuh kepastian hukum, yang mana perkembangan dan problematika hukum sangat sulit diprediksi. Ungkapan Rasulullah SAW berikut ini menggambarkan kehadiran seseorang dalam perubahan sosial yang akan menuntun manusia agar tidak tertinggal dengan perubahan. Aspek hukum merupakan salah satu bagian yang sering tertinggal apabila dibandingkan dengan pranata sosial lainnya. Teks hadisnya adalah:

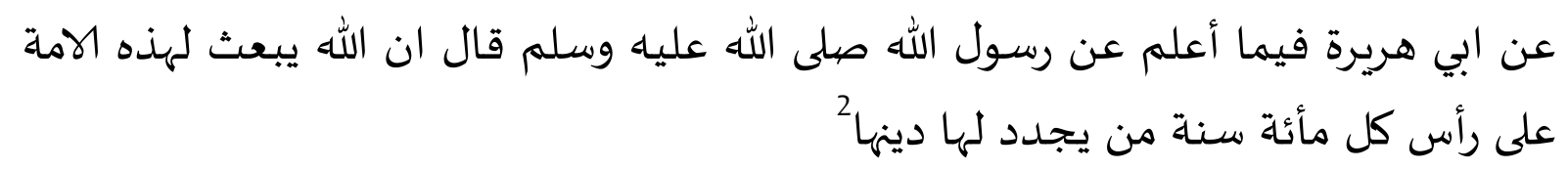

Artinya:

"Dari Abu Hurairah sebagaimana aku ketahui dari Rasulullah SAW bersabda, sesungguhnya Allah SWT akan mengutus pada setiap seratus tahun orang yang memperbaharui agamanya". 
Semangat dari hadis di atas adalah pentingnya pembaharuan secara dinamis antara perkembangan sosial dan hukum Islam secara timbal balik. Kata seratus tahun tidak hanya dapat dimaknai secara nominal karena Hadis tersebut berperan sebagai ادلة bukan تجديد .مصادر (pembaharuan) mengandung arti membangun kembali, menyusun kembali atau memperbaiki baik pola pikir maupun praktek keagamaan agar dapat dipergunakan sebagaimana yang diharapkan. ${ }^{3}$ Kandungan makna تجديد di-Indonesia-kan dengan pembaharuan.

Pembaharuan hukum sangat penting dilakukan, maka mujaddid perlu segera dihadirkan. Mesin pembaharuan hukum adalah ijtihad. Ijtihad adalah proses berpikir positiffuturistik yang diarahkan pada pengambilan langkah-langkah antisipatif dari berbagai kemungkinan dan tantangan baru yang secara terus-menerus dimunculkan oleh sifat evolusionisme kehidupan. Disadari sepenuhnya bahwa di dunia Islam, kebebasan manusia dan kebebasan berfikir tidak lahir dari suatu proses sejarah sebagaimana yang terjadi di dunia Barat. Kebebasan berfikir berpangkal dari ajaran Islam itu sendiri. ${ }^{4}$ Ini adalah modal besar jika ijtihadnya tidak salah arah yang membuat potensi ijtihad jadi nyasar. Dengan ijtihad akan terjadi perubahan persepsi dan praktek keagamaan yang mapan kepada pemahaman dan pengamalan yang baru yang lebih adabtable dan bermaslahat. ${ }^{5}$

Tuntutan pembaharuan merupakan bagian dari proses pengujian pemahaman dan pengamalan keagamaan agar tidak kehilangan arah atau semakin menjauh dari sumbernya. Rentang waktu seratus tahun sangat dimungkinkan terjadi pergeseran pemahaman maupun pengamalan hukum karena dorongan faktor subjektif seperti egois dan tingkat pemahaman maupun faktor objektif seperti waktu dan tempat.

Pergeseran pemahaman dan praktek thalaq di dalam masyarakat pada masa pemerintahan Umar bin Khattab sehingga beliau perlu membuat perubahan hukum melalui kebijakan bahwa thalaq yang diucapkan tiga sekaligus karena ada unsur main-main tetap dinyatakan sah, dan terhitung tiga. Untuk itulah pembaharuan merupakan upaya pengujian hukum agar tetap berada dalam koridor standar kebenaran.

Dimensi hukum Islam ada dua yakni dimensi ilahiyah dan dimensi insaniyah. Dimensi insaniyah adalah upaya manusia secara sungguh-sungguh untuk memahami hukum Islam yang akan dijadikan sebagai jawaban atas persoalan publik. Dimensi inilah yang yang mungkin bisa mengalami perubahan. ${ }^{6}$ 


\section{B. Perubahan Hukum}

Perubahan hukum dapat dilihat melalui perubahan penguatan bobot secara konkret terhadap norma yang abstrak sehingga menjadikan pengaturannya bisa bertahan lama maupun perubahan aturan secara formal. Hukum berfungsi mengaktifkan bekerjanya berbagai faktor perubahan. ${ }^{7}$

Perubahan hukum terkait dengan motivasi pembuat hukum, waktu, tempat, kondisi tertentu. Dalam masyarakat pluralis, transformasi merupakan kemestian. Memahami transformasi hukum Islam ke dalam tatanan sosial membutuhkan perhatian serius terhadap perubahan sosial. Dengan demikian klaim bahwa hukum Islam sulit menerima perubahan sosial tidak akan muncul. Langkah ini sekaligus dapat dijadikan bahan untuk membangun kerangka kerja dalam mengembangkan sistem hukum yang responsif. Watak hukum Islam adalah menyentuh langsung realitas sosial tanpa jarak, sehingga ia berada dalam tatanan kehidupan masyarakat secara kuat dan berkeadilan, sekaligus menghargai pluralisme dan kemanusiaan universal. ${ }^{8}$

Seiring dengan perkembangan zaman, situasi dan kondisi pun mengalami perubahan yang cukup signifikan hingga menuntut reformasi hukum Islam, mengingat bahwa tuntutan perkembangan hukum pada masa penulisan kitab-kitab fikih awal sudah berbeda dengan tuntutah hukum kekinian. Reformasi hukum Islam tersebut terjadi demi:

1. Mengisi kekosongan hukum karena norma-norma yang terdapat dalam kitab fikih tidak mengaturnya ditengah kebutuhan masyarakat akan hukum yang baru sangat mendesak untuk diterapkan.

2. Memaknai glonalisasi dan perkembangan ilmu pengetahuan dan sains modern sehingga perlu ada hukum yang mengaturnya.

3. Mengisi peluang sebagai acuan bahan hukum dalam berbagai bidang pada era kontemporer.

4. Maksimalisasi peran para mujtahid.

Berbagai faktor di atas menuntut adanya perubahan hukum. Imam al-Syafi'i melalui Qaul Qadim nya di Baghdad-lrak mengalami perkembangan dan perubahan hukum menjadi Qaul Jadid di Kairo-Mesir, suatu tuntutan sosio-legal. Ini sejalan dengan kaedah tagayyir alahkam bi tagayyir al-zaman wa al-amkan. Ini sekaligus menunjukkan bahwa faktor sosiokultural mempengaruhi perkembangan dan pembinaan hukum Islam, ${ }^{9}$ masalah-masalah dan perubahan hukum bukanlah suatu yang absolut atau abadi. ${ }^{10}$ 
Di era kontemporer kini, Yusuf al-Qardhawi menawarkan alternatif perubahan hukum Islam melalui metode:

1. Ijtihad Intiqa' $i$, suatu metode kaji ulang hasil ijtihad para ulama sebelumnya secara komprehensif, memkomparasikan dan mengambil pendapat yang kuat sesuai dengan kriteria dan kaidah tarjih dan alat pengukurnya. Alat-alat pengukur pen-tarjih-an selain dalil yang kuat, juga harus sesuai dengan waktu peruntukan hukum tersebut, cakupan makna rahmat bagi semesta, prinsip taisir (kemudahan). dan kemaslahatan pengguna hukum itu sendiri.

2. Ijtihad Insya'i, yakni menentukan hukum dalam persoalan yang belum pernah dikemukakan oleh mujtahid sebelumnya. Seperti dalam penggunaan foto sebagai jati diri. Ada yang menganggap foto itu gambar. Padahal, ada Hadits yang melarang orang menggambar. Maka, pendapat baru mengatakan foto itu bukan gambar yang dilarang. Karena Nabi melarang gambar membuat bandingan makhluk Allah. Sedang foto adalah bayangan refleksi seperti dalam kaca, dan bayangan itu dengan alat moderen direfleksikan dalam kertas. Dengan demikian, perubahan sosial yang terus bergulir secara dinamis harus diimbangi dengan model hukum yang dapat mengontrol perubahan maupun yang akan mengadalkan rekayasa sosial masyarakat.

Agar pelaksanaannya efektif dan menghasilkan suatu hukum yang dapat menyelesaikan suatu masalah maka ijtihad insya-i dilakukan secara kolektif (jama'i). Ijtihad kolektif antara pengguna hukum dengan pembuat hukum diperkirakan akan menghasilkan hukum yang lebih seksama dan akurat karena bisa saling memberi, melengkapi, bekerjasama antar ulama mujhahid dan para pakar dari berbagai disiplin ilmu. Dalam diskusi tersebut akan muncul berbagai macam kepentingan yang berragam dan berbeda, yang akan dipadukan dalam musyawarah mufakat dalam mencari solusi hukum dengan pemikiran cerdas yang akan menyatukan dan menyelamatkan umat.

Terkait dengan karakter hukum Islam yang fleksibel dan elastis dalam menerima perubahan, perlu dipertegas beberapa istilah yang ada kaitannya dengan perubahan tersebut yakni syariat, fikih, dan hukum Islam. Syariat adalah ketentuan yang telah baku yang dimuat dalam al-Qur'an dan hadis. Sedangkan fikih adalah pemahaman terhadap syariah oleh Faqih agar aturan yang tercantum dalam syariat tersebut dapat dioperasionalisasikan, sementara term Hukum Islam merupakan istilah khas Indonesia, lebih dekat kepada pengertian fikih. ${ }^{11}$ Hukum Islam dalam pengertia fikih tersebut secara fungsional dapat berperan sebagai rujukan dan sekaligus sebagai alat rekayasa sosial (social engineering). 


\section{Inspirasi Hukum Islam}

Jika perubahan dapat direkayasa, maka hukum Islam pun dapat merekaysa masyarakat menjadi masyarakat yang berbudaya. Hukum Islam dalam bentuk fikih merupakan produk ijtihad para mujtahid bersifat dinamis, bergerak dan dapat mengikuti dan membuat perkembangan masyarakat pada setiap zaman dan tempat. Hukum Islam hadir sebagai pemberi inspirasi solusi hukum, baik dalam konteks kontrol maupun rekayasa sosial, sehingga memunculkan idiom setiap aturan yang mengandung kemaslahatan, itu adalah hukum Islami $^{12}$ Prinsip-prinsip hukum Islam tetap menjadikan kemaslahatan sebagai orientasinya. Fleksibelitasnya dalam praktik menunjukkan ia adaptif terhadaap perubahan sosial dan mampu merekayasa hukum yang bermaslahat, dinamis dan relevan untuk setiap zaman, keadaan dan tempat. ${ }^{13}$

Apabila ada pemahaman bahwa hukum Islam tidak mengalami perubahan dan pembaharuan, tentu ini akan membuat hukum Islam mengalami kesulitan dalam tataran aplikasinya. Kehidupan moderen yang didukung kedigdayaan teknologi sekarang ini menimbulkan perubahan prilaku sosial di masyarakat. Disinilah dituntut adanya suatu tatanan hukum Islam yang mengatur prilaku sosial masyarakat berdasarkan nilai transendensi. Ulama dan pemerhati hukum Islam dituntut untuk merumuskan dan menetapkan yang adaptifaplikatif baik sebagai jawaban terhadap suatu permasalahan yang timbul, maupun dalam bentuk peraturan untuk menata kehidupan manusia.

Reaktualisasi hukum Islam membuatnya selalu hidup dan berada pada masyarakat. Terjadinya interaksi antara perubahan hukum dan perubahan sosial adalah suatu kenyataan. Perubahan sosial akan memunculkan tuntutan supaya hukum Islam yang mengatur masyarakat turut berkembang bersamanya. ${ }^{14}$ Hukum Islam sebagai bagian dari hasil produk pemikiran ulama itu rasional, jelas, metodologis, dan aktual, sehingga ia adaptif terhadap perubahan. Adaptif terhadap perubahan sekaligus merekayasa agar terjadi perubahan ke arah yang lebih bermaslahat dalam setiap pranata sosial yang ada. ${ }^{15}$ Pranata sosial dapat dilihat dari segi:

1. Aktualisasi hukum Islam bertumpu pada interaksi sosial yang terpola dari pergumulan dengan kaedah-kaedah lokal yang dianut oleh masyarakat majemuk sehingga memunculkan adaptasi dan modifikasi. Proses sosilaisasi dan internalisasi hukum Islam terjadi dalam hubungan timbal balik dengan kaedah -kaedah lokal yang dianut. 
2. Pranata-pranata merupakan wujud dari interaksi sosial dalam masyarakat Islam untuk memenuhi kebutuhan mereka. Interaksi itu berpatokan pada nilai-nilai, keyakinan, kaidah yang mereka anut. ${ }^{16}$

Ada tiga pranata sosial umat Islam yang menurut Cik Hasan Basri ${ }^{17}$ memiliki sensivitas yang tinggi yaitu pranata peribadatan, pranata kekerabatan, dan pranata pendidikan. Ketiga pranata ini memiliki tingkat kepekaan lebih tinggi dari pranata ekonomi, politik, keilmuan dan lain-lain. Oleh karena itu alokasi hukum Islam atau nilai-nilai hukum Islam pada umumnya terintegrasi ke dalam ketiga pranata itu secara maksimal, sehingga menjadi basis masyarakat Islam dalam konteks pergaulan hidup secara global.

\section{Hukum Islam sebagai Sarana Rekayasa Sosial}

Dalam konteks ke-Indonesia-an, hukum Islam sebagai sarana rekayasa sosial dapat dilaksanakan melalui jalur transformasi kedalam bentuk perundang-undangan (Qanun). Transformasi ini dikenal juga dengan istilah positivisasi. Ini melalui jalur politik. Pendekatan politik yang dilaksanakan umat Islam dalam merespon tautan ketiga pranata peribadatan, pranata kekerabatan dan pranata pendidikan itu dapat terlihat, antara lain, dari proses lahirnya Undang-Undang Nomor tahun 1974 tentang Perkawinan (dalam hal pranata kekerabatan), Peraturan Pemerintah (PP) Nomor 28 tahun 1977 tentang Perwakafan Tanah Milik (pranata peribadatan) termasuk juga Undang-Undang Nomor 7 tahun 1989 tentang Pengadilan Agama (PA) sebgai pendukung atau pelembagaan pranata kekerabatan dan peribadatan serta Undang-Undang Nomor 2 tahun 1989 tentang Sistem Pendidikan Nasional (pranata pendidikan).

Dalam hal pranata kekerabatan, tuntutan unifikasi hukum tentang perkawinan telah menggema begitu lama, mengingat aturan yang berlaku bagi masyarakat Indonesia dalam waktu yang relatif cukup lama sangat variatif, mulai dari yang berdasarkan hukum adat (tidak tertulis), hukum Islam (tertulis tapi tidak dalam bentuk undang-undang), ordonisasi perkawinan Kristen dan Burgerlijk Wetboek (BW) atau hukum perdata warisan penjajahan Belanda (keduanya berbentuk undang-undang). Selain sumber hukum yang beragam, hukum perlu ditetapkan untuk menertibkan administrasi perkawinan dan perilaku poligami masyarakat yang sulit dideteksi. Akibat dari perilaku tersebut banyak hak-hak isteri dan anakanak yang terabaikan. Dalam hal ekonomi dapat dilihat seperti Peraturan Pemrintah Nomor 72 tahun 1992 tentang Bank Bagi Hasil. 
Positivisasi hukum Islam di Indonesia dengan tidak merubah tujuan dan substansinya merupakan contoh konkrit hukum Islam yang adaptif dan merekayasa dan membuatnya tetap aktual. Perubahan pranata-pranata sosial yang terjadi dalam masyarakat tidak selalu beriringan dan memiliki tingkat perkembangan yang sama antar satu pranata dengan pranata lainnya. Oleh karena itu apabila deretan perubahan yang terjadi dalam suatu pranata sosial sangat berbeda dengan pranata sosial lainnya, besar kemungkinan akan terjadi konflik di tengah masyarakat tersebut. Untuk menarik garis perubahan yang relatif sejajar dalam pranata sosial itulah dibutuhkan aturan hukum yang memiliki bobot untuk 'memaksa'. Positivasi hukum Islam merupakan upaya penerapan hukum Islam dengan daya paksa untuk merekayasa perubahan sosial masyarakat ke arah yang lebih bermaslahat. Pendaya-gunaan hukum sebagai saran rekayasa sosial menurut skenario kebijakan pemerintah dalam kasus Indonesia sangat efektif. Kebijakan-kebijakan seperti itu juga masih dibutuhkan negara industri maju meskipun mekanisme hukumnya telah berjalan dan lancar. ${ }^{18}$

Imran $^{19}$ berpendapat bahwa memang negaralah seharusnya yang berkewajiban membuat aturan hukum formal yang memiliki daya 'memaksa' tersebut, karena negaralah yang memiliki sarana untuk mengadaptasi berbagai aturan untuk mengubah lingkungan, memiliki kekuatan menegeliminir aturan yang lama, futuristis dalam setiap tindakan hukumnya serta negara telah melengkapi aturan-aturan adat yang belum tertulis demi kepastian hukum yang akan disosialisasikan dengan mudah dapat dilembagakan. Dalam konteks seperti inilah urgensitas hukum Islam dilembagakan secara formal oleh negara agar lebih mudah diketahui, dipahami, dinilai, dihargai, dijiwai, diterapkan, ditaati, membudaya dalam masyarakat sekaligus memmbuat suatu proses perubahan. ${ }^{20}$

Pelembagaan hukum Islam secara formal oleh negara adalah proses transformasi hukum Islam ke dalam hukum positif negara setelah diadakan pengkajian yang mendalam, kemudian diformulasikan ke dalam bahasa hukum yang baku. Kendala yang sering ditemui dalam proses pengkajian tersebut adalah sulitnya ditemukan lembaga-lembaga atau pusat kajian keislaman unggulan. Pengkajian akademik dibidang hukum Islam sering tertinggal karena:

1. Secara historis pusat-pusat pengkajian kurang respons terhadap perkembangan dan dinamika sosial sehingga relatif sulit untuk dikembangkan atau ditumbuhkan.

2. Pengkajian hukum Islam berada diantara pengkajian agama Islam dan pengkajian ilmu hukum. Eksesnya adalah aspek yang masuk melalui ilmu hukum tidak begitu mendalam dan demikian juga sebaliknya aspek yang masuk ilmu agama juga kurang memadai. ${ }^{21}$ 
Pelembagaan nilai-nilai hukum Islam (islamisasi hukum nasional) relatif lebih mudah dilaksanakan daripada nasionalisasi hukum Islam, karena tidak harus membawa label Islamnya. Pelembagaan nilai-nilai hukum Islam ini umumnya barlaku dalam bidang hukum netral, sedangkan nasionalisasi hukum Islam relatif lebih sulit memperjuangkannya karena biasanya manyangkut hukum yang tidak netral seperti hukum material yang menjadi kompetensi absolut Pengadilan Agama di Indonesia.

KH. Syachul Hadi ${ }^{22}$ bahkan menginginkan agar seluruh hukum Islam dapat di transformasikan ke dalam hukum positif, agar hukum Islam tidak tinggal dalam kitab-kitab fikih atau tradisi-tradisi yang hidup di tengah masyarakat saja. Beliau melihat isi kandungan hukum Islam itu marketable dalam peraturan sosial-politik di Indonesia. Trend kodifikasiunifikasi hukum berusaha memberikan 'cetak biru' atau kepastian hukum di tengah pluralisme yang tidak hanya terjadi di Indonesia dan negara berkembang lainnya tetapi juga pada tingkat internasional seperti lembaga Perserikatan Bangsa-Bangsa (PBB) ${ }^{23}$ Fleksibilitas hukum Islam dalam beradaptasi dengan perubahan sosial yakni terlihat dalam kaedah hukum berikut:

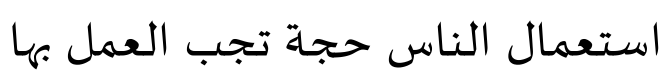

Artinya: "apa yang biasa diperbuat orang banyak,merupakan hujjah yang wajib dilaksanakan".

Hukum harus berada pada posisi kebutuhan dan tindakan mayoritas agar hukum dapat fungsional di tengah perkembangan yang ada. ${ }^{24}$ "Kesukaran mendatangkan kemudahan”.Adaptasi hukum dimaksudkan agar hukum tersebut tidak menjadi perangkap bagi pengguna hukum yang membuat mereka merasa kesulitan. עرار ولا ضرار, “Tidak boleh mebuat kemudaratan pada diri sendiri dan membuat kemudaratan kepada orang lain”. الضرر "kemudratan haruis dihilangkan"

\section{E. Cara Hukum Islam Merespon Perubahan Sosial}

Kehadiran persoalan-persoalan baru ditengah masyarakat, akibat perkembangan zaman dan perubahan sosial masyarakat sehingga secara tekstual maupun kontektual tidak ditemukan ketentuan-ketentuan tentang persoalan tersebut, maka dalam hukum Islam ada cara lain yang dapat dilakukan untuk merespon perubahan tersebut, yang tentuny tetap mengacu kepada al-Qur'an dan sunnah. Adapun cara tersebut antara lain sebagai berikut $:^{25}$ 
1. Qiyas

Setelah Rasulullah SAW wafat, secara otomatis sunnah pun terhenti sementara persoalan hukum semakin komplek yang membutuhkan ketentuan hukum, maka para ulama berupaya mencari jawabannya dari al-Qur'an dan sunnah dengan pendekatan analogi induktif yaitu penalaran yang berangkat dari peristiwa khusus ke suatu kejadian yang khusus pula dengan menyimpulkan bahwa kebenaran pada kasus tertentu benar pula untuk kasus yang lain, yang dalam hukum Islam disebut metode qiyas.

Qiyas berasal dari kata qasa, yaqisu, qaisan artinya mengukur, mempersamakan, mengukur sesuatu dengan yang lainnya, atau penyamaan sesuatu dengan sejenisnya. Maka sederhananya, qiyas adalah menyamakan sesuatu yang tidak ada hukumnya dengan sesuatu yang ada hukumnya karena adanya persamaan illat. Illat secara etimologi berarti sesuatu yang menyebabkan berubahnya keadaan sesuatu yang lain dengan keberadaannya, dan secara terminologi adalah satu sifat yang nyata yang terang tidak bergeser-geser yang dijadikan pergantungan sesuatu hukum. Dengan kata lain, menetapkan hukum pada kasus baru dengan menyamakan suatu putusan hukum yang mirip dan sudah jelas hukumnya di masa lalu.

Contohnya keharaman khamr, menurut sebagian ulama bahwa illatnya bukan semata karena memabukkan melainkan khamr itu sendiri sebab apabila diminum sedikit tidak akan memabukkan. Maka setiap minuman mereka dan jenis apapun yang mengandung khamr secara otomatis hukumnya haram untuk diminum sekalipun sedikit.

2. Ijma'

Ijma secara etimologi, berarti konsensus atau kesepakatan, sedangkan menurut terminologi ijma' adalah kesepakatan para ulama secara kolektif pada satu masa setelah wafatnya Rasulullah SAW dalam menetukan suatu hokum berdasarkan al-Qur'an dan sunnah, baik lisan, tulisan, maupun isyarat yang menerangkan persetujuan atas pendapat mujtahid lainnya pada zamannya, atau memilih diam saja menanggapi pendapat tersebut tidak mengeluarkan pendapatnya maka sebagian ulama memaknai diam tersebut dengan setuju. Namun sebagian ulama membagi ijma' yaitu, kesepakatan semua ulama sahabat dalam suatu masalah pada masa tertentu disebut ijma' sahabat, kesepakan khalifah Abu Bakar, Umar, Usman dan Ali pada suatu masalah disebut ijma' khulafaur rasyidin, kesepakatan para ulama Madinah pada masa tertentu disebut ijma' ulama Madinah, dan kesepakatan ulama-ulama Kuffah tentang suatu masalah disebut ijma' ulama Kufah. 
Sederhananya, ijma' adalah hasil musyawarah mufakat seluruh ulama mujtahid dalam rangka mengistinbath suatu hukum. Pada masa dulu, para mujtahid masih sedikit dan terbatas sehingga memungkinkan kala itu untuk melakukan ijma'. Sementara ijma' di zaman sekarang sangat sulit untuk mengumpulkan para mujtahid sedunia guna musyawarah mufakat menetapkan suatu hukum. Yang ada sekarang, hanyalah musyawarah mufakat komunitas ulama atau institusi tertentu saja yang disebut fatwa,yaitu jawaban berdasarkan ijtihad atas pertanyaan mengenai hukum suatu peristiwa yang belum jelas hukumnya seperti fatwa Majelis Ulama Indonesia (MUI). Terlebih lagi dewasa ini, umat Islam sudah terpecah belah membuat yang namanya ijma' tidak memungkinkan lagi, sementara kompleksitas persoalan hukum semakin meluas, maka tidak heran terkadang hanya dilakukan oleh seorang berijtihad secara individual guna menemukan jawaban hukum terkini.

3. Ijtihad

Ijtihad menurut etimologi, diambil dari akar kata bahasa Arab jahada sebagai bentuk kata masdarnya jahdun yang berarti kesungguhan, sepenuh hati, serius atau pencurahan semua kemampuan untuk mendapatkan urusan sesuatu. Sedangkan secara terminologi ,adalah upaya sungguh-sungguh para ulama mujtahid untuk menetapkan sesuatu putusan hukum Islam berdasarkan al-Qur'an dan sunnah bukan pendapat pribadi belaka, terutama persoalan kontemporer yangbelum dibahas secara detail dalam al-Qur'an dan sunnah. Mengenai ijtihad, pada persoalan tertentu yang belum dijelaskan secara implisit dalam alQur'an dan sunnah dibolehkan menentukan sendiri hukumnya, sebagaimana dijelaskan Allah SWT dalam al-Qur'an surah al-Maidah ayat 101 sebagai berikut :

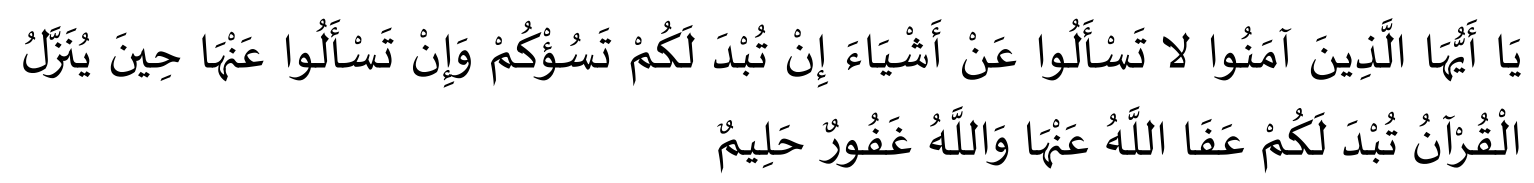

Artinya :

"Hai orang-orang yang beriman! janganlah kamu menanyakan (kepada nabimu) hal-hal yang jika diterangkan kepadamu, (justru) menyusahkan kamu.Jika kamu menanyakan ketikaal-Qur'an sedang diturunkan, (niscaya) akan diterangkan kepadamu. Allah SWT telahmemaafkan (kamu) tentang hal itu. Dan Allah SWT Maha Pengampun lagi Maha Penyantun." $\{$ Qs. Al-Maidah/5:101 \}

Khusus ijtihad ini, hanya belaku pada persoalan muamalah atau duniawi yang pada dasarnya masih bersifat dhanni (berubah), merujuk kepada kaidah hukum Islam asl $f i$ asyai ibahah hatta yaquma dalilu'ala buthlani au 'ala ttahrim yang menyatakan bahwa 
asal segala yang bersifat duniawi dibolehkan sepanjang tidak da dalil yang melarangnya, sehingga memungkinkan untuk dikembangkan sesuai dengan perkembangan masyarakat dan perubahan zaman seperti jual beli, sewa menyewa, hutang piutang, gadai, dan lain sebagainya. Maka yang berkaitan dengan ekonomi, sosial, ketatanegaraan, politik, dan budaya hanya memberikan ide dasarnya saja yang selanjutnya secara praktis diserahkan kepada insan manusia itu sendiri. Bukan untuk persoalan ibadah yang bersifat qath 'i (kekal) sudah diterangkan secara terperinci, dan merujuk kepada kaidah hukum Islam asl fi ibadah buthlanun hatta yaquma dalil 'ala amr yang menyatakan bahwa asal segala ibadah hukumnya dilarang dilakukan kecuali ada dalil yang memerintahkannya, sehingga tidak berubah sepanjang masa dan tidak akan terpengaruh dengan perkembangan zaman.

\section{F. Penutup}

Manusia dengan akal rasionalnya akan merencanakan perubahan disamping lingkungan sosial yang berubah secara natural. Perubahan yang terjadi bersama pranata-pranata sosial terkadang mengalami goncangan dan perlu penyesuaian, proses adaptasi. Proses adaptasi sosial adalah proses penyesuaian terhadap perubahan lingkungan dan merubah lingkungan agar sesuai dengan kebutuhan manusia. Proses-proses tersebut membutuhkan kehadiran hukum sebagai penengah sekaligus penggagas.

Hukum Islam dengan karakternya yang fleksibel dan elastis dapat memainkan peran fungsionalnya ditengah perubahan dan proses adaptasi tersebut yang membuat hukum Islam itu dapat hidup dan berfungsi lebih baik bagi penggunanya. Hukum Islam sebagai sarana rekayasa sosial dapat dilakukan melalui positivisasi melalui jalur peng-qanun-an oleh negara agar memiliki daya paksa. Pembaruan pemikiran hukum Islam adalah suatu bagian yang tidak terpisahkan dari proses kehidupan masyarakat yang selalu berubah. Maka perubahan sosial masyarakat membutuhkan perubahan hukum. Peranan qanun sebagai perubahan hukum dalam bentuk rekayasa sosial.

Kemampuan memperedsiksi peristiwa hukum dalam perubahan soaial merupakan keniscayaan hukum Islam untuk dapat memberi jawaban fungsional. Dalam konteks ini, pemaknaan hukum Islam melalui perspektif nilai dan keterkaitan secara organik dan struktural dalam kehidupan sosial. Di sinilah letak pentingnya fenomena transformasi pemikiran hukum Islam. Fenomena keagamaan dan fenomena sosial saling berinteraksi. Transformasi pemikiran hukum Islam merupakan suatu pergumulan kreatif antara Islam dengan sosial masyarakat, antara nilai-nilai Islam dengan kenyataan struktural masyaraka 


\section{DAFTAR PUSTAKA}

Ahmaed Akgunduz, Islamic Law in the Theory and Practice: Introduction to Islamic Law, Rotterdam: Uir Press, 2010

Amir Syarifuddin, Ushil Fikih Jilid 1, Jakarta: Kencana, 2008

Amrullah Ahmad,(ed), Prospek Hukum Islam Terhadap Pengembangan Hukum Nasional di Indonesia: Sebuah Kenangan 65 Tahun Prof. Dr. H. Bushtanul arifin, SH, (Jakarta: PP-IKAHA, 1994

Cik Hasan Bisri, Peradilan Islam dan Tatanan Masyarakat Indonesia, Bandung: Remaja Rosdakarya, 1997

Dede Ismatullah, Sejarah Sosial Hukum Islam, Bandung: Pustaka Setia, 2011

Fatimah Halim, "Hukum dan Perubahan Sosial” UIN Alauddin Makassar, 2018

George Ritzer, Sosiologi IlmuPengetahuan Berparadigma Ganda, Jakarta: PT. Raja Grafindo Persada, t.t.

Gunawan, Hendra,. Karakteristik Hukum Islam, Jurnal Al-Maqasid; Jurnal Ilmu Kesyariahan dan Keperdataan Fakultas Syariah dan Ilmu Hukum IAIN Padangsidimpuan, Vol. 4 No. 2. Edisi Juli-Desember 2018.

Ghufron A Mas'adi, Pemikiran Fazlur Rahman tentang Metodologi Pembaharuan Hukum Islam, Jakarta: RajaGrafindo Persada, 1997.

Ibn Rusyd, Bidayat al-Mujtahid wa Nihayat al-Muqtashid, Indonesia: Dar al-Kutub al'Arabiyyah, t.t.

Imran mengikuti pendapat HLA. Hart, lihat Imran Ahsan Khan, Theories of Islamic Low, Islamabad: Islamic Reseach Institute Press, 1945.

Jaih Mubaraok, Sejarah dan Perkembangan Hukum Islam, Bandung: Remaja Rosdakarya, 2000.

Kamus Sosiologi Antropologi, Penerbit Indah Surabaya, 2001.

Lahmuddin Nasution, Pembaharuan Hukum Islam Dalam Mazhab Syafi'i, Bandung: PT. Remaja Rosdakarya, 2001.

Moh. Mahfud MD, (ed), Peradilan Agama dan Kompilasi Hukum Islam dalam Tata Hukum Indonesia, Yogyakarta: UII Press, 1993.

Muhammad Khalid Mas'ud, Filsafat HukumIslam: Studi Tentang dan Pemikiran Abu Ishaq al-Shatibi, Bandung: Pustaka, 1996.

Mun'im A. Sirry, Sejarah Fikih Islam: Sebuah Pengantar, Surabaya: Risalah Gusti, 1995.

Musa, Tarīkh al-Fikih al-Islamī, Mesir: Dar-al-Kitab al-'Arabi, 1958.

Soerjono Soekanto, Pokok-Pokok Sosiologi Hukum, Jakarta: PT Raja Grafindo Persada, 1988.

Soetandyo Wingjosoebroto, dari Hukum Kolonial ke Hukum Nasional: Dinamika Sosial Politik dalam Perkembangan Politik di Indonesia, Jakarta: Raja Grafindo Persada, 1994.

Yayan Sopyan, Tarikh Tasyri': Sejarah Pertumbuhan Hukum Islam, Jakarta: Gramata Publishing, 2010. 


\section{End Note :}

${ }^{1}$ Ghufron A Mas'adi, Pemikiran Fazlur Rahman tentang Metodologi Pembaharuan Hukum Islam, (Jakarta: RajaGrafindo Persada, 1997), hlm. 57-58.

${ }^{2}$ Abu Daud, Sunan Abu Daud, (t.tp: Dar al-Fikr, tt), jilid IV, hlm. 109

${ }^{3}$ Louis Ma'luf, al-Munjid al-Abady, (Lebanon: Dar al-Masyriq, 1986), hlm. 229

${ }^{4}$ Haidar Bagir (ed), Ijtihad Dalam Sorotan, (Bandung: Mizan, 1988), hlm. 18 dan 79.

${ }^{5}$ Toha Andiko, "Peluang dan Tantangan Ijtihad dalam Pembaruan Hukum Islam" dalam Jurnal Nuansa, Edisi1, No. 2 September 2010, hlm. 179-184.

hlm. vii.

${ }^{6}$ Jaih Mubaraok, Sejarah dan Perkembangan Hukum Islam, (Bandung: Remaja Rosdakarya, 2000),

${ }^{7}$ Fatimah Halim, “Hukum dan Perubahan Sosial” UIN Alauddin Makassar, 2018, hlm. 6

${ }^{8}$ Kata pengantar Azyumardi Azra dalam Yayan Sopyan, Tarikh Tasyri': Sejarah Pertumbuhan Hukum Islam, (Jakarta: Gramata Publishing, 2010), hlm. iii

${ }^{9}$ Dedi, Sejarah..., hlm. 344

${ }^{10}$ Mun'im A. Sirry, Sejarah Fikih Islam: Sebuah Pengantar, (Surabaya: Risalah Gusti, 1995), hlm. 110

${ }^{11}$ Fikih menghasilakan pemikiran yang zann sebagai lahan ijtihad. Zann vis a vis dengan qath' $i$ yang secara umum dipahami orang bukan lahannya ijtihad. Tetapi Ibrahim Hosen mengemukakan ada beberapa contoh teks yang qath' $i$ tetapi bisa di-fikih-kan. Mem-fikih-kan yang qath'i. Lihat juga Ahmaed Akgunduz, Islamic Law in the Theory and Practice: Introduction to Islamic Law, (Rotterdam: Uir Press, 2010, hlm. 19-22

${ }^{12}$ Dede Ismatullah, Sejarah Sosial Hukum Islam, (Bandung: Pustaka Setia, 2011), hlm. 7

${ }^{13}$ Musa, Tarīkh al-Fikih al-Islamī (Mesir: Dar-al-Kitab al-’Arabi, 1958), h. 14. Sumber lain dapat dilihat dalam Muhammad Khalid Mas'ud, Filsafat Hukum Islam: Studi Tentang dan Pemikiran Abu Ishaq alShatibi, (Bandung: Penerbit Pustaka, 1996), hlm. 23-24

${ }^{14}$ Lahmuddin Nasution, Pembaharuan Hukum Islam Dalam Mazhab Syafi'i, (Bandung: PT. Remaja Rosdakarya, 2001), hlm. 254.

${ }^{15}$ Dedi Ismatullah, Sejarah Sosial Hukum Islam, (Bandung: Pustaka Setia, 2011), hlm. 374

${ }^{16}$ Dedi, Sejarah......, h. 371

${ }^{17}$ Cik Hasan Bisri, Peradilan Islam dan Tatanan Masyarakat Indonesia, (Bandung: Remaja Rosdakarya, 1997), hlm. 13

${ }^{18}$ Soetandyo Wingjosoebroto, dari Hukum Kolonial ke Hukum Nasional: Dinamika Sosial Politik dalam Perkembangan Politik di Indonesia, (Jakarta: Raja Grafindo Persada, 1994), hlm. 231

${ }^{19}$ Imran mengikuti pendapat HLA. Hart, lihat Imran Ahsan Khan, Theories of Islamic Low, (Islamabad: Islamic Reseach Institute Press, 1945), hlm. 103

${ }^{20}$ Syechul Hadi Permana, "Sosialisai Inpres Nomor 1 tahun 1991 tentang Pemasyarakatan Kompilasi Hukum Islam" dalam Moh. Mahfud MD, (ed), Peradilan Agama dan Kompilasi Hukum Islam dalam Tata Hukum Indonesia, (Yogyakarta: UII Press, 1993), hlm. 110

${ }^{21}$ Zarkowi Soejoeti mengemukakan pada saat RUUPA diajukan ke DPR muncul reaksi yang dilatar belakangi kekurang-pahaman mereka terhadap hukum Islam. Seandainya pusat kajian hukum Islam unggulan banyak memberikan pemahaman tentang hukum Islam tersebut, maka yang muncul adalah sikap apresiasi, penghargaan dan sikap mau mengerti terhadap hukum Islam. Zarkowi Soejoeti "Diperlukan Pusat Pengkajian Hukum Islam yang Berwibawa" dalam Amrullah Ahmad,(ed), Prospek Hukum Islam Terhadap Pengembangan Hukum Nasional di Indonesia: Sebuah Kenangan 65 Tahun Prof. Dr. H. Bushtanul arifin, SH, (Jakarta: PPIKAHA, 1994), hlm. 371

${ }^{22}$ Syechul Hadi, "Sosialisasi..., hlm. 111

${ }^{23}$ A. Dzazuli, "Beberapa Aspek Pengembangan Hukum Islam di Indonesia” dalam Eddi Rudiana Arief, dkk, Hukum..., hlm. 234

${ }^{24}$ Nash Majallat al-Ahkam, No. 17

${ }^{25}$ Hendra Gunawan,. Karakteristik Hukum Islam, Jurnal Al-Maqasid; Jurnal Ilmu Kesyariahan dan Keperdataan Fakultas Syariah dan Ilmu Hukum IAIN Padangsidimpuan, Vol. 4 No. 2. Edisi Juli-Desember 2018, hlm. 114-117. 